Article

\title{
Cyclic Behavior Associated with the Degassing Process at the Shallow Submarine Volcano Tagoro, Canary Islands, Spain
}

\author{
Eugenio Fraile-Nuez ${ }^{1, * \mathbb{D}}$, J. Magdalena Santana-Casiano ${ }^{2}$, Melchor González-Dávila ${ }^{2}$, \\ Juan T. Vázquez ${ }^{3}{ }^{\mathbb{D}}$, Luis Miguel Fernández-Salas ${ }^{4}{ }^{(D)}$, Olga Sánchez-Guillamón ${ }^{3}{ }^{\mathbb{D}}$, \\ Desirée Palomino $^{3}$ id and Carmen Presas-Navarro ${ }^{1}$ \\ 1 Instituto Español de Oceanografía, Centro Oceanográfico de Canarias, Santa Cruz de Tenerife 38180, Spain; \\ carmen.presas@ieo.es \\ 2 Instituto de Oceanografía y Cambio Global, Universidad de Las Palmas de Gran Canaria, \\ 35017 Las Palmas de Gran Canaria, Spain; magdalena.santana@ulpgc.es (J.M.S.C.); \\ melchor.gonzalez@ulpgc.es (M.G.D.) \\ 3 Instituto Español de Oceanografía, Centro Oceanográfico de Málaga, 29640 Málaga, Spain; \\ juantomas.vazquez@ieo.es (J.T.V.); osanchezguillamon@gmail.com (O.S.G.); desiree.palomino@ieo.es (D.P.) \\ 4 Instituto Español de Oceanografía, Centro Oceanográfico de Cádiz, 11006 Cádiz, Spain; \\ luismi.fernandez@ieo.es \\ * Correspondence: eugenio.fraile@ieo.es; Tel.: +34-922-54-94-00
}

Received: 17 October 2018; Accepted: 29 November 2018; Published: 4 December 2018

\begin{abstract}
Tagoro, the most recently discovered shallow submarine volcano on the Canary Islands archipelago, Spain, has been studied from the beginning of its eruptive phase in October 2011 until November 2018. In March 2012, it became an active hydrothermal system involving a release of heat and gases that produce significant physical-chemical anomalies in the surrounding waters close to the seabed. Fast Fourier transform (FFT) and wavelet time-domain-frequency analysis techniques applied to filtered time series of temperature, salinity, pressure, $\mathrm{pH}$, and oxidation-reduction potential (ORP) data from a conductivity-temperature-depth (CTD) device mounted on a mooring and deployed at the deepest part of the main crater at a depth of $127 \mathrm{~m}$, have been used to better understand the dynamic processes of the emissions during Tagoro's degasification phase. Our results highlight that the hydrothermal system exhibited a stationary cyclic degassing behavior with a strong peak of a 140-min period centered on a significant interval of 130-170 min at 99.9\% confidence. Moreover, important physical-chemical anomalies are still present in the interior of the main crater, such as: (i) thermal increase of $+2.55{ }^{\circ} \mathrm{C}$, (ii) salinity decrease of -1.02 , (iii) density decrease of $-1.43\left(\mathrm{~kg} \cdot \mathrm{m}^{-3}\right)$, and (iv) $\mathrm{pH}$ decrease of -1.25 units. This confirms that, five years after its origin, the submarine volcano Tagoro is still actively in a degassing phase.
\end{abstract}

Keywords: hydrothermal vents; cyclic behavior; submarine volcano; Tagoro; El Hierro

\section{Introduction}

Shallow hydrothermal vents are located in different tectonic settings, in particular related to recent subaerial and submarine volcanic activity, along arcs and mid ocean ridges, and in areas presenting intraplate oceanic volcanism [1-5]. Hydrothermal emissions are associated with the release of heat and gases, and acidic and reduced metal-rich fluids [6-8]. The chemical composition of hydrothermal fluids changes as the deep and shallow systems are affected by variations in permeability, induced by seismic events and related to fluid overpressures. These emissions significantly affect the properties of seawater and marine sediments [9,10], changing geochemical processes and mineralization patterns [11]. 
Hydrothermal vents have been studied in terms of fluid geochemistry characterization, physical-chemical processes [3,12,13], and biological communities [14]. Fewer studies have been carried out on the water dynamics in the near field of hydrothermal vents $[13,15,16]$. Water dynamics can change with the intensity of the flux of fluids and with seismic activity in the area [17]. It has been observed that the effect of pressure fluctuation with tide can generate intermittent behavior in the bubble jet of shallow hydrothermal vents [15]. Emissions of gases, fluids, and heated water from hydrothermal vents generate upward convective plumes in the area that can be advected and diluted, depending on the dynamics and energy of the system [18]. At shallow depths, vent plumes are usually small [19]. Moreover, in these areas, where hydrostatic pressure is not the major force controlling gas dilution and water boiling, vents are of the hydrothermal type, with high flow rates of free gas, principally $\mathrm{CO}_{2}$, and many diffusive and sparse columns of gas bubbles are frequent $[15,16,20,21]$.

Volcanic eruptions often show cyclic trends in their rate of occurrence over a range of timescales [22-26]. Seismic and acoustic volcano monitoring signals also show systematic cyclicity $[25,27,28]$. However, the processes underlying such cyclic activity remain uncertain. Volcanic degassing provides crucial information on the dynamics of magmatic systems and eruptions [24,29-31]. Although several studies reveal the existence of cyclic behaviors in the release of heat and gases from different sub-aerial volcanoes [24-26,32-34] and underwater volcanic systems $[18,23,35]$, oceanic volcanoes have received less attention. Hydrothermal vents occur globally in deep and shallow oceans, although records of shallow vents are less numerous than for those found in the deep sea [36-43].

In October 2011, at La Restinga-El Mar de Las Calmas Marine Reserve, a submarine volcano eruption took place $1.8 \mathrm{~km}$ south of the coast of El Hierro $\left(27^{\circ} 37.116^{\prime} \mathrm{N}, 017^{\circ} 59.466^{\prime} \mathrm{W}\right.$, Figure 1). During the next six months, extreme physical-chemical perturbations caused by this event, comprising thermal changes, water acidification, deoxygenation, and metal enrichment, resulted in significant alterations of the marine ecosystem [44,45]. After March 2012, once the eruptive phase was over, the submarine volcano Tagoro entered an active hydrothermal phase that involved a release of heat, gases, and metals [21].

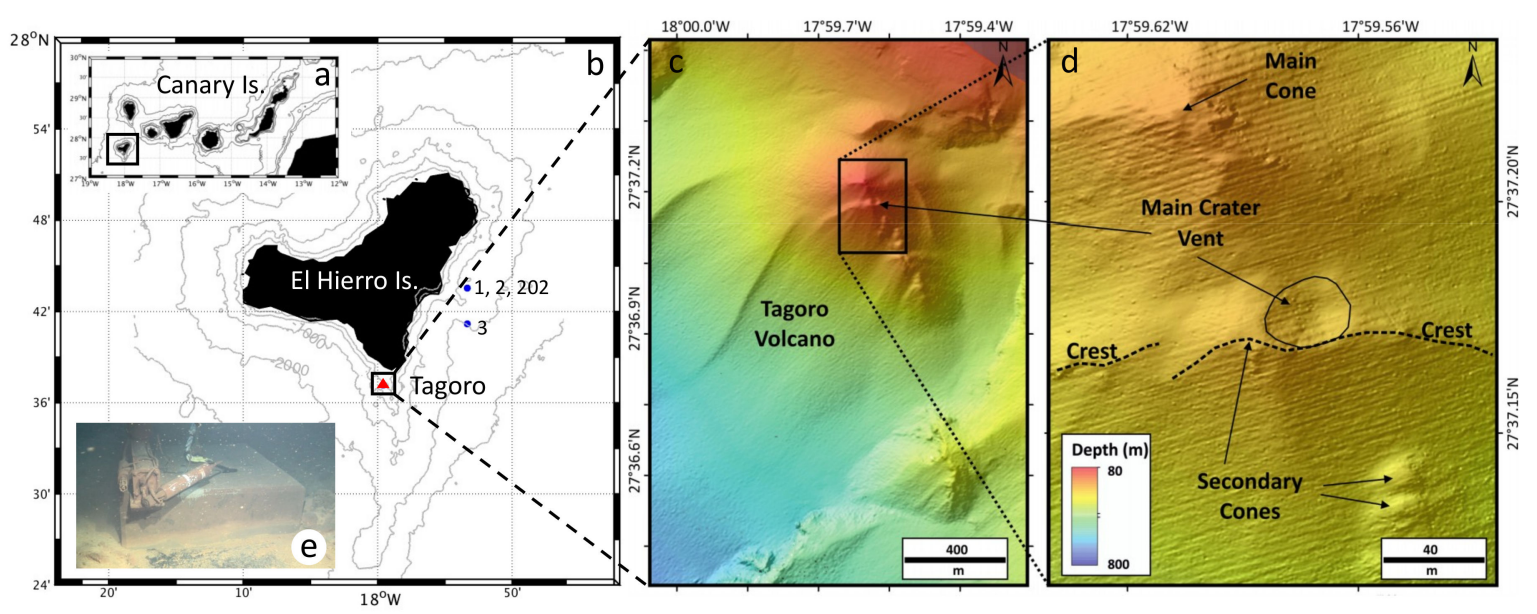

Figure 1. Location map. (a) Location of the island of El Hierro in the Canary Archipelago. (b) Locations of the Tagoro submarine volcano and the CTD ref. stations. (c) High resolution bathymetry of Tagoro submarine volcano. (d) High resolution bathymetry zoon at the area of the main crater vent. (e) Image from the ROV of the mooring deployed at the interior of the main crater vent before its recovery (Vulcana-II-0417).

The Tagoro volcano has a basanitic nature and is monogenetic, generated entirely during the underwater eruption that took place between October 10, 2011 and March 5, 2012 (Figure 1c-d). The eruption took place at a $355 \mathrm{~m}$ depth on the southern submarine promontory off El Hierro Island, on the western wall of a submarine gully with a NNE-SSW direction. From this moment, 
the volcano grew through several pulses of activity, forming a main cone located NW of the starting point, with a summit at a $88 \mathrm{~m}$ depth. Subsequently, volcanic vents were successively formed to the SSE of the main cone, generating alienated secondary cones and the final geometry of the volcano. The eruption generated three main volcanic domains, situated progressively deeper to the SW: the Tagoro volcano s.s., a lava-debris flow apron, and a lobe like body. The first sector, where this work has been carried out, corresponds to a slightly elongated volcanic cone that rises from a 400 to $88 \mathrm{~m}$ depth. The edifice has slopes between 20 and $45^{\circ}$, which are steepest close to the different volcanic vents and smoother in lower flank areas. It has an irregular base (1-1.3 $\mathrm{km}$ in diameter) and an elongated summit in a NNW-SSE direction.

This volcanic edifice is characterized by several volcanic vents which produced at least 14 volcanic cones located in the axis of the edifice. The diameter of the main cone is $400 \mathrm{~m}$, and those of the 13 secondary cones vary between 75 and $140 \mathrm{~m}$, decreasing in size towards the SSE. Minor depressions are also differentiated close to the secondary cones, with diameters ranging from 15 to $35 \mathrm{~m}$. The most pronounced has been located on top of an ENE-WSW arc-shape crest at approximately a $116 \mathrm{~m}$ depth, where the second-highest volcanic cone is also located. This crest corresponds to an internal discontinuity between the main edifice and the SSE prolongation of secondary cones. In this context, this main crater vent (Figure 1d) has a circular shape, with a length of $35 \mathrm{~m}$ and depth of 126-130 m. It has an asymmetric geometry as a consequence of its development on an inclined surface. The north-western rim walls correspond to the volcano's main flank, with slopes ranging from 20 to $35^{\circ}$ and height relative to the depression floor of up to $13 \mathrm{~m}$, while the south-eastern rim walls are characterized by a minor crest of a $3 \mathrm{~m}$ height and slopes varying from 12 to $18^{\circ}$. This depression corresponds to the location of the main hydrothermal vent at present. Although the whole crater worked as a diffuse degassing system, the degassing process was even more visible at specific areas covered by chimney fields (5-10 cm high) and cracks (Figure 2). This crater vent and its out-gassing source were first monitored in the column water with CTD exploration, tow-yos transects, and ROV images by this research team [21].

As one of the newest and shallowest active submarine volcanoes in Europe, the Tagoro volcano is an excellent natural laboratory to study the dynamics associated with the degasification process. Here, we report significant physical-chemical anomalies and a cyclic degassing dynamic at Tagoro, five years after the beginning of the degasification phase, with a complete time series of temperature, salinity, pressure, $\mathrm{pH}$, and oxidation-reduction potential (ORP) data from an RBR CTD device and a Seabird $27 \mathrm{pH}$-ORP sensor mounted on a mooring in the deepest point of the main crater at a $127 \mathrm{~m}$ depth $\left(27^{\circ} 37.178^{\prime} \mathrm{N}, 017^{\circ} 59.574^{\prime} \mathrm{W}\right.$, Figure $\left.1 \mathrm{~d}-\mathrm{e}\right)$. 

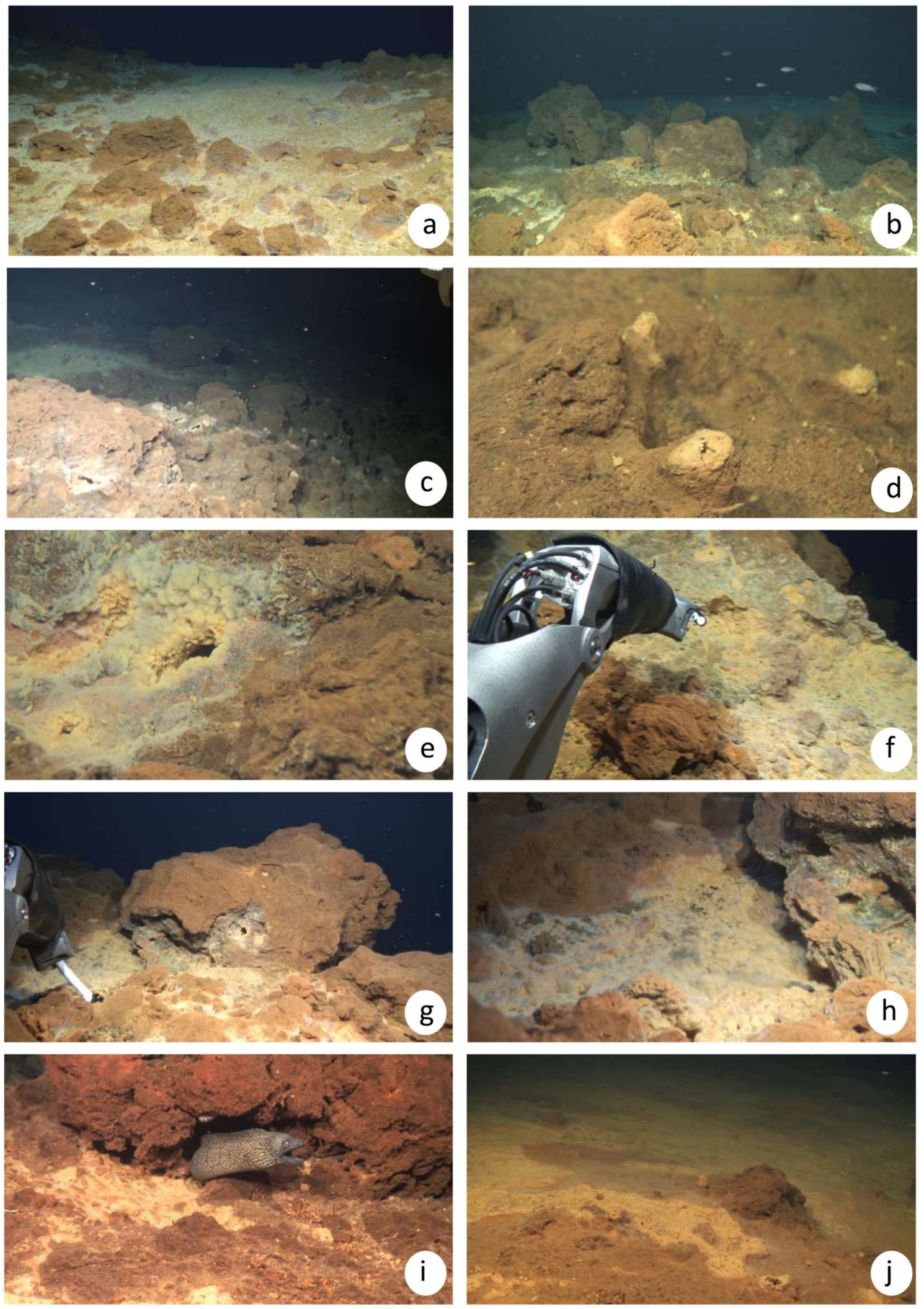

Figure 2. High definition images from a remotely operated vehicle (ROV) of the Spanish Institute of Oceanography at the interior of the main crater vent of Tagoro submarine volcano, between a $124-130 \mathrm{~m}$ depth, collected during the Vulcana-II-1118 cruise in November 2018. (a-j) show different perspectives from the degassing process in the interior of the crater with the presence of bacterial mat areas, chimneys fields, and cracks. 


\section{Materials and Methods}

In October 2016, five years after the completion of the magmatic activity, a multidisciplinary oceanographic cruise in the context of the VULCANO-II project was carried out in order to characterize the physical-chemical anomalies of the underwater volcano in a degassing stage (Figure 1a-b). During this cruise, on board R/V Ángeles Alvariño of the Spanish Institute of Oceanography, a mooring equipped with an RBR CTD device (RBR, Ottawa, ON, Canada) and a Seabird $27 \mathrm{pH}$-ORP sensor (Sea-Bird Electronics, Bellevue, WA, USA) was deployed at the deepest point of the more active crater of the Tagoro submarine volcano at a $127 \mathrm{~m}$ depth (Figure 1e). The accuracy of the temperature, conductivity, $\mathrm{pH}$, and ORP sensors was $0.002{ }^{\circ} \mathrm{C}, 0.003 \mathrm{~S} / \mathrm{m}, 0.02$ units, and $1.0 \mathrm{mV}$, respectively. The sensors were calibrated at the point of manufacture before and after deployment, and for the time of the observation, no drift was observed.

The mooring was deployed on 10 October 2016. The sensors were programmed to start sampling at the same moment, but due to an internal problem with the hard drive of the datalogger, the CTD was operative only during the first eight days, from 30 October 2016 to 6 November 2016, with a sampling interval of ten seconds, while the pH-ORP sensor was operative for 41 days, from 13 November 2016 to 24 December 2016, with a sampling interval of three minutes. For this last data series, the first 15 days, from 30 October 2016 to 12 November 2016, were missed. The mooring was recovered during the VULCANA-0417 cruise in April 2017, in the context of the VULCANA project of the Spanish Institute of Oceanography using a Super Mohawk II ROV Liropus 2000 (Sub-Atlantic, Aberdeen, UK). The different time series were resampled every five minutes and a high-pass filter with a cut-off of five hours was applied in order to eliminate low frequencies, such as diurnal and semidiurnal tides and inertial signatures.

In order to evaluate and quantify the anomalies and the variability of the physical-chemical properties in the area exclusively due to the volcanic activity, as a reference, a dataset of the mean profiles of every variable was obtained using four full hydrographical CTD stations placed at the east part of the island (Figure 1b, stations 1, 2, 202, and 3). These stations were not influenced by the perturbations of the submarine volcano at this time. The obtained reference data are, hereafter, denoted ref-mean. CTD profiles were carried out using a Seabird 911+ with a double sensor of temperature and conductivity, together with a $2410-\mathrm{L}$ bottle carousel for water samples. The accuracy of the temperature and conductivity sensors was $0.001{ }^{\circ} \mathrm{C}$ and $0.0003 \mathrm{~S} / \mathrm{m}$, respectively.

A bathymetric digital elevation model of the seafloor was obtained with data from a Kongsberg Simrad EM-710 multibeam echosounder (Kongsberg Maritime AS, Kongsberg, Norway) (70 to $100 \mathrm{kHz}$ ), with a spatial grid resolution of $1 \mathrm{~m}$ (Figure 1c-d), which allowed us to detect and localize the main crater ( $35 \mathrm{~m}$ diameter) of the submarine volcano Tagoro in order to deploy the mooring at the deepest point of the crater (127 m depth). This was possible due to the accuracy of the bathymetry data and the dynamic position (DP) system of the oceanographic vessel Ángeles Alvariño.

High definition images from an ROV of the Spanish Institute of Oceanography have been used to describe the geomorphology of the main crater and determinate the presence of the chimney and diffuse vent area. Images were collected during Vulcana-II-0417 and Vulcana-II-1118 cruises, in April 2017 and November 2018, respectively.

The nature of the fluctuations of different properties was investigated using two different time series analysis techniques. The first was a modification of a Fast Fourier Transform (FFT) [46,47], which provides information on the signal power content at any frequency, but loses the frequency location in the time domain. This widely used technique is designed for stationary signals; however, our time series could have contained non-stationary or transitory characteristics, such as drifts, trends, abrupt changes, onsets, and even ends of events. These characteristics are often the most important part of the signal, and Fourier analysis is not suited for their detection [24]. For this reason, we applied the wavelet transform (WT), which, in contrast to the FFT, consists of a linear superposition of independent and non-evolving periods that preserves frequency location in the time domain $[48,49]$. 
In that way, wavelet power spectra can provide better time and frequency localization than Fourier transform-based methods, due to being more suitable for analyzing cyclicity in non-stationary time series [50]. We used a Morlet wavelet and the Matlab code toolbox of Grinsted [51].

\section{Results}

Five years after the end of the eruptive phase of the submarine volcano Tagoro, south of the island of El Hierro, important physical-chemical anomalies are still present in the area. Non-affected vertical profiles of potential temperature, $\theta\left({ }^{\circ} \mathrm{C}\right)$; salinity, S; potential density, $\sigma_{\theta}\left(\mathrm{kg} \cdot \mathrm{m}^{-3}\right)$; and $\mathrm{pH}$ (NBS scale) with depth $(\mathrm{m})$ for the whole water column as a mean of the stations $(1,2,202$, and 3) with their standard deviation are shown in Figure 3. Affected data recorded by the sensors located at the mooring at the interior of the crater are shown in red. Our results show, in reference to the ref-mean values, that the hydrothermal system exhibited maximum physical-chemical anomalies, with an increase in potential temperature of $+2.55^{\circ} \mathrm{C}$, a decrease in salinity of -1.02 , a decrease in density of $-1.43 \mathrm{~kg} \cdot \mathrm{m}^{-3}$, and a decrease in $\mathrm{pH}$ of -1.25 units. Table 1 shows the minimum, maximum, and mean values with standard deviation, ref-mean values of non-affected water at the depth of the main crater $(127 \mathrm{~m})$, and the maximum anomalies found in the area.
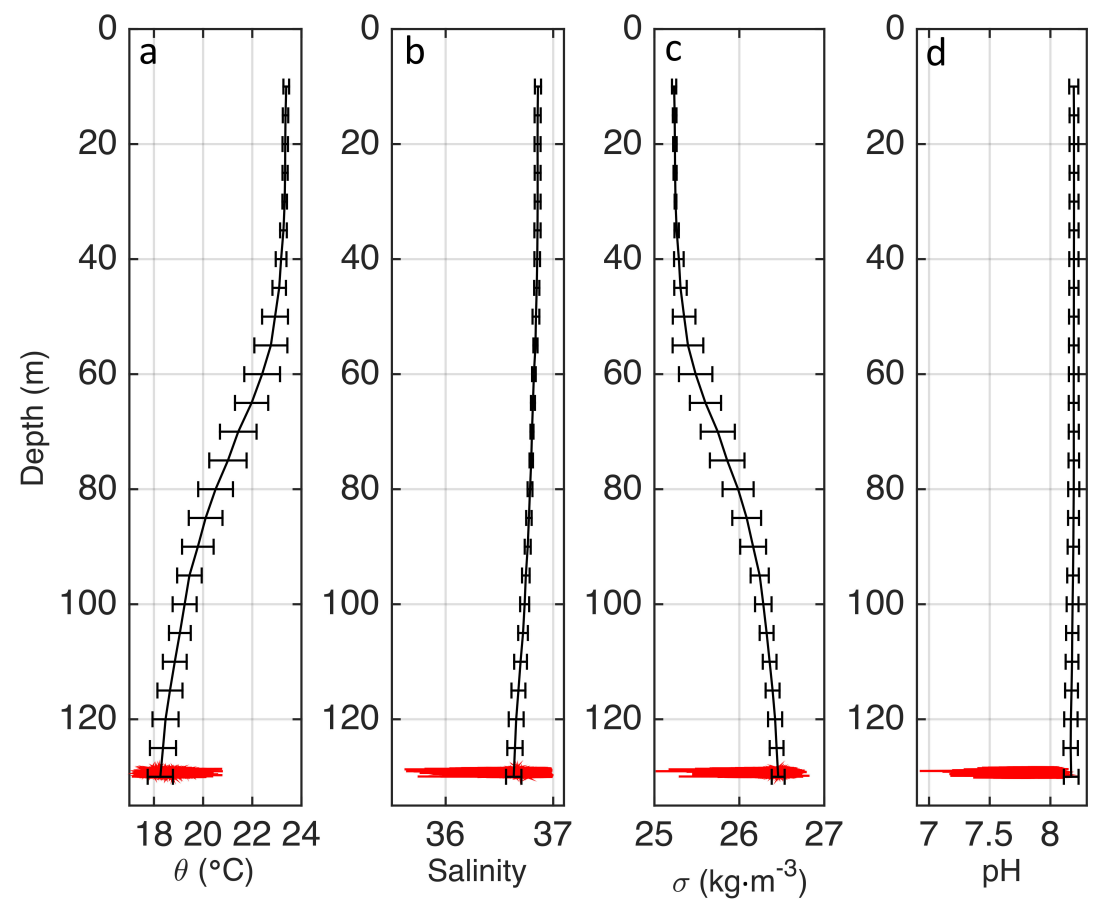

Figure 3. Vertical profile of (a) potential temperature, (b) salinity, (c) potential density, and (d) $\mathrm{pH}$, with their standard deviation at the reference stations not affected by the emissions of the submarine volcano. Time series of the same parameters, but recorded by the mooring at the interior of the main crater at a $127 \mathrm{~m}$ depth are shown in red.

Table 1. Potential temperature, salinity, potential density, and $\mathrm{pH}$ statistics. Minimum, maximum, and mean values with their standard deviation, maximum anomalies found in the area, and ref. mean values of non-affected water at the depth of the main crater $(127 \mathrm{~m})$.

\begin{tabular}{cccccc}
\hline Variable & Minimum & Maximum & Mean \pm Standard & Maximum Anomaly & Reference Mean \\
\hline$\theta\left({ }^{\circ} \mathrm{C}\right)$ & 17.10 & 20.80 & $18.47 \pm 0.41$ & +2.55 & $18.26 \pm 0.51$ \\
\hline Salinity & 35.62 & 36.99 & $36.64 \pm 0.08$ & -1.02 & $36.63 \pm 0.07$ \\
\hline$\sigma_{\theta}\left(\mathrm{kg} \cdot \mathrm{m}^{-3}\right)$ & 25.03 & 26.83 & $26.41 \pm 0.10$ & -1.43 & $26.46 \pm 0.07$ \\
\hline $\mathrm{pH}(\mathrm{NBS}$ units $)$ & 6.92 & 8.17 & $7.86 \pm 0.14$ & -1.25 & $8.17 \pm 0.06$ \\
\hline
\end{tabular}


Low salinity in the water column above the main crater is directly associated with substantial positive temperature anomalies. Such low-salinity fluids are likely to form in a relatively shallow (low pressure) phase-separating hydrothermal system $[52,53]$ that can separate seawater into two conjugate fluids: a condensed-vapor low-salinity fluid and a residual brine. Although a less-dense low-salinity fluid was present in greater proportion $\left(\mathrm{Sal}<\mathrm{Sal}_{\text {ref }}\right)$, the higher density fluid $\left(\mathrm{Sal}>\mathrm{Sal}_{\text {ref }}\right)$ was also sampled. Thus, variation in the thermohaline properties may produce a hydrothermal positive buoyancy that causes plumes to rise, with the rise-height limited by the steep density gradients in the water column at the depth of approximately $60 \mathrm{~m}$.
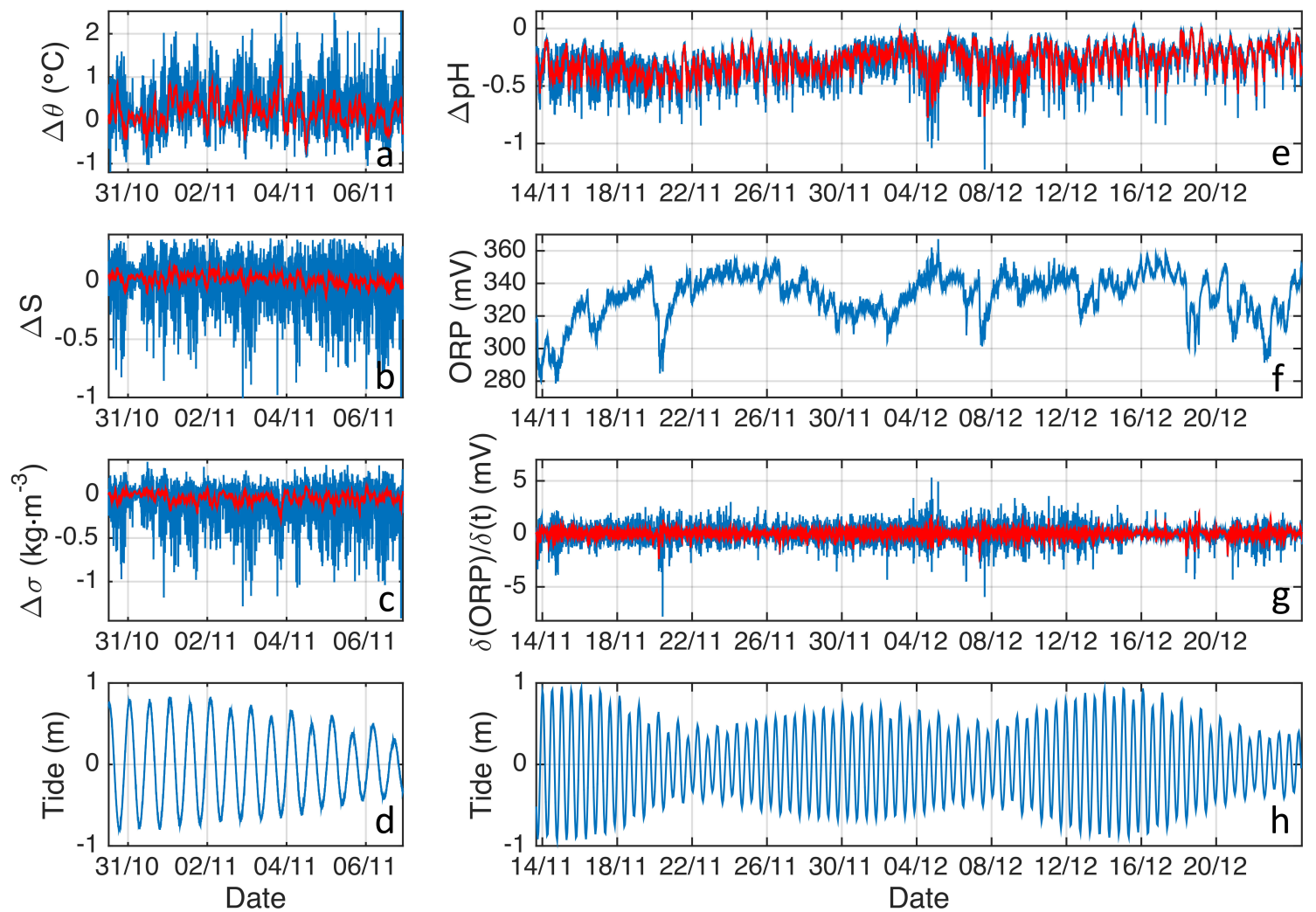

Figure 4. Time series of (a) potential temperature anomaly, (b) salinity anomaly, (c) potential density anomaly, (d) pressure, (e) $\mathrm{pH}$ anomaly, (f) oxidation-reduction potential (ORP), and (g) $\partial(\mathrm{ORP}) / \partial \mathrm{t}$ recorded by an RBR CTD and Seabird $27 \mathrm{pH}$-ORP system mounted at a mooring deployed at the interior of the main crater at a depth of $127 \mathrm{~m}$ during October-December 2016. (h) Theoretical tide extracted by [54]. Red color shows the five-minute moving average time series.

In order to isolate the release of heat and gases from the main crater of the shallow submarine volcano Tagoro, a complete time series of the anomalies recorded by the combined CTD-pH-ORP sensors installed at the mooring at a depth of $127 \mathrm{~m}$ has been studied. Anomalies of potential temperature, salinity, and potential density, respectively, together with a five-minute moving average, are represented in Figure $4 \mathrm{a}-\mathrm{c}$. Sea surface elevation derived from the analysis of the pressure data sensor of the CTD device is presented in Figure 4d. Similarly, Figure 4e-g show the $\mathrm{pH}$ anomaly, ORP time series, and the first time derivative of the ORP data, respectively, with a five-minute moving average for $\mathrm{pH}$ and $\partial(\mathrm{ORP}) / \partial \mathrm{t}$. Finally, Figure $4 \mathrm{~h}$ shows the theoretical tide for this period of time [54] (pressure data not available).

Two different time-domain-frequency analysis techniques have been applied to the filtered time series for potential temperature, salinity, and pressure, respectively (Figure 5a1-a3): the power spectra and statistical significance were computed by a modification of fast Fourier transform [46] (Figure 5b1-b3) and wavelet analysis (Figure 5c1-c3). The results of the time-frequency analysis show a strong peak of over $99.9 \%$ significance present in the decomposition of the potential temperature, 
salinity, and pressure time series anomalies, with a period centered at approximately $140 \mathrm{~min}$ and included in a significant interval of 130-170 min. This significant peak explains $41 \%$ of the total variance of the signal. The results obtained by power spectral analysis are consistent with those obtained by wavelet analysis (Figure 5c1-c3), and show significant spectral power (highlighted by the black line at 95\% confidence level), mainly between 80 and 160 min with stationary features. Other signals, centered around $40 \mathrm{~min}$, appear not to be steady, but localized in time.
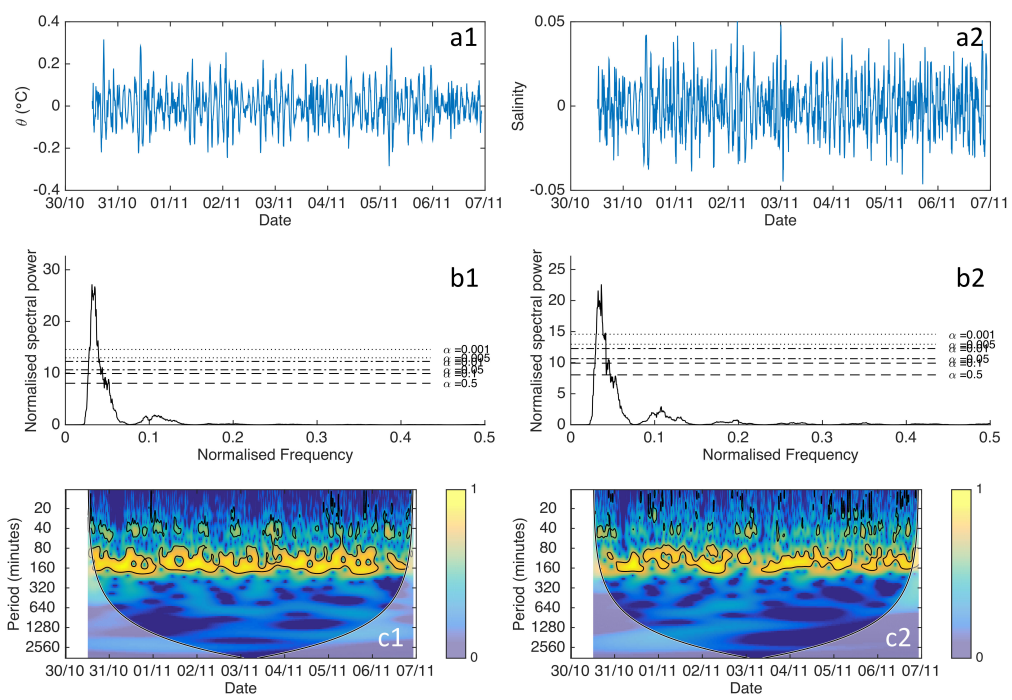
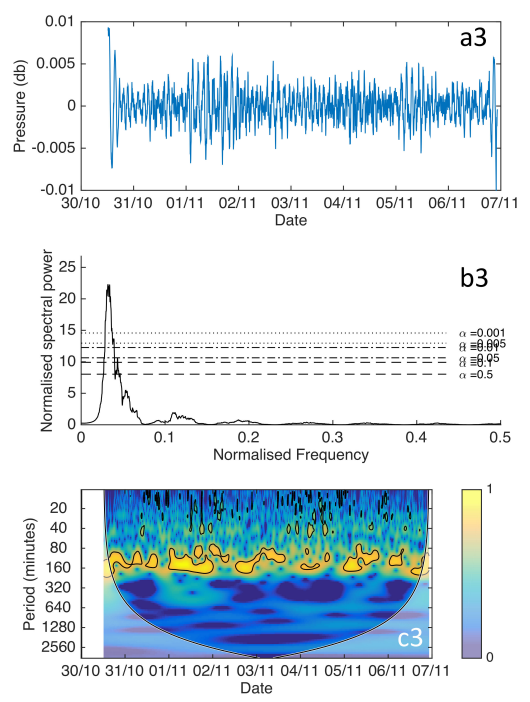

Figure 5. Filtered time series of potential temperature (a1), salinity (a2), and pressure (a3) from an RBR CTD device mounted in a mooring at the interior of the main crater at a $127 \mathrm{~m}$ depth. (b1-b3) are the corresponding power spectra and statistical significance computed by fast Fourier transform (FFT). (c1-c3) are the application of the wavelet transform. The solid contour shows the $95 \%$ confidence interval and the light shaded region the cone of influence, representing the area where the wavelet spectrum is affected by edge effects.

Figure 6 shows the application of FFT and wavelet time-domain-frequency analysis techniques applied to $\mathrm{pH}$ and $\partial(\mathrm{ORP}) / \partial \mathrm{t}$ time series, with the longest obtained from the interior of the main crater by the sensors located at the mooring (Figure 6a1-a2). The results of the time-frequency analysis show a significant interval of 100-165 min, with the peak centered at 145 min (Figure 6b1-b2). Wavelet analyses show identical responses for both variables, with significant spectral power mainly between 80 and 160 min with stationary features, and other signals centered around 40 min and localized in specific time intervals (Figure $6 c 1-c 2$ ). Thus, the same significant peak has been obtained during the application of the time-frequency analysis to the five independent variables studied in this work (temperature, salinity, pressure, $\mathrm{pH}$, and ORP). 

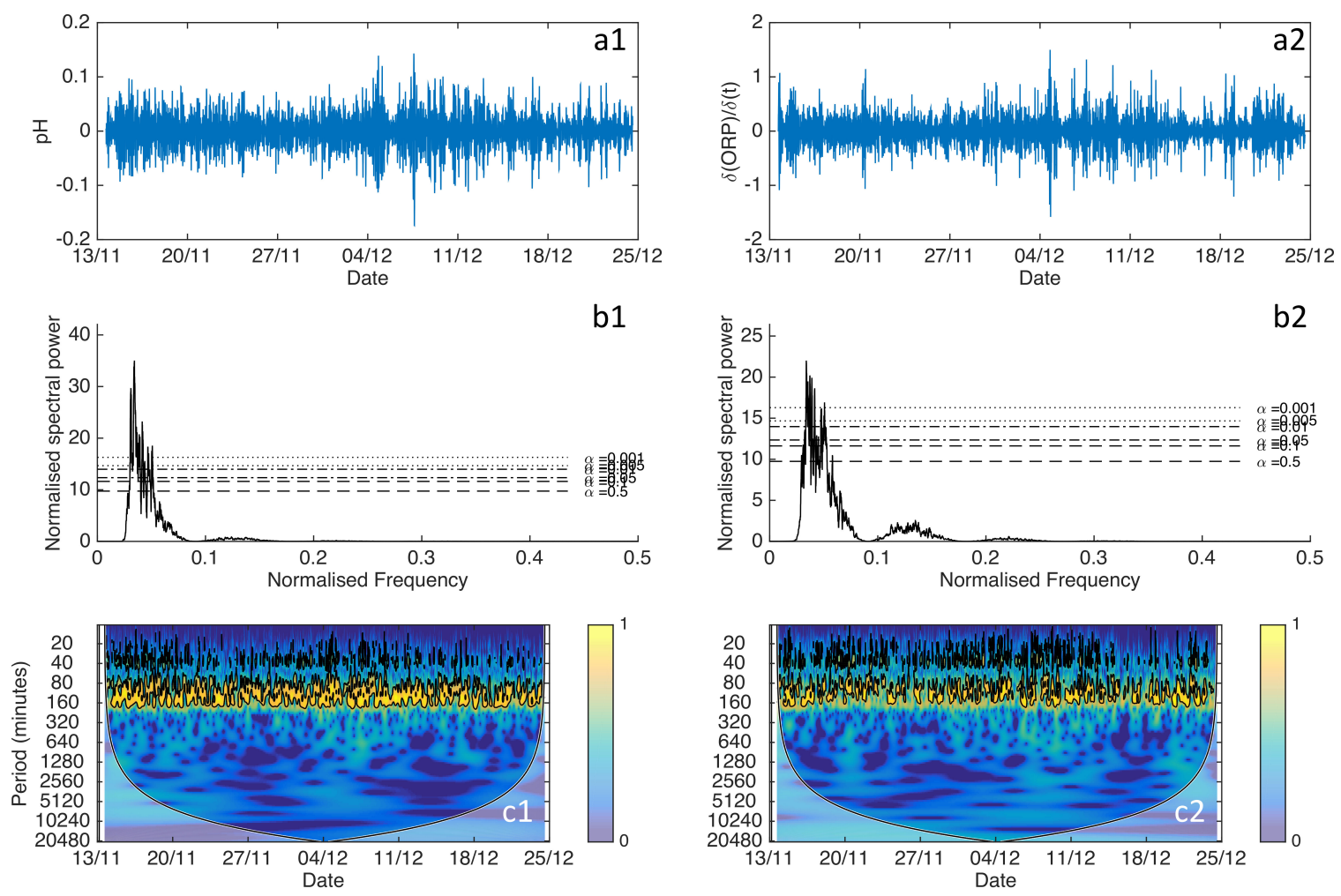

Figure 6. Filtered time series of $\mathrm{pH}(\mathbf{a} 1)$ and $\partial(\mathrm{ORP}) / \partial \mathrm{t}(\mathbf{a} 2)$ from a $\mathrm{pH}-\mathrm{ORP}$ sensor mounted in a mooring at the interior of the main crater at a $127 \mathrm{~m}$ depth. (b1-b2) are the corresponding power spectra and statistical significance computed by fast Fourier transform (FFT). (c1-c2) are the implementation of the wavelet transform. The solid contour shows the $95 \%$ confidence interval and the light shaded region the cone of influence, representing the area where the wavelet spectrum is affected by edge effects.

\section{Discussion}

Through this study, different time series of temperature, salinity, pressure, $\mathrm{pH}$, and ORP from the deepest part $(127 \mathrm{~m})$ of the main crater of the submarine volcano Tagoro have been studied in order to (a) quantify the physical-chemical anomalies of the degassing process, and (b) apply different time-frequency analysis techniques to determinate significant cyclic behavior in the release of hydrothermal fluids.

Our results show that, five years after the beginning of the degassing process, thermal anomalies up to $+2.55{ }^{\circ} \mathrm{C}$, salinity anomalies up to -1.02 , density anomalies up to $-1.43\left(\mathrm{~kg} \cdot \mathrm{m}^{-3}\right)$, and $\mathrm{pH}$ anomalies up to -1.25 units were still observed in the interior of the main crater. Our reference profiles (Figure 2) show that water masses with salinity anomalies of -1.02 could be found in the water column at a depth of $550 \mathrm{~m}$ or deeper. In the case of $\mathrm{pH}$ (Figure 3d), water masses with $\mathrm{pH}$ anomalies of -1.25 are too acidic to be found in the first $2000 \mathrm{~m}$ of the water column in the Canary Islands region [45]. According to these assumptions, these physical-chemical anomalies should be due to the release of hydrothermal fluids from the vents around the volcanic edifice of Tagoro and not to upwelling from deeper water masses around the area.

Previous results obtained in the same area, but in the water column around the main crater with the use of a rosette, show an increase in temperature of $+3.0^{\circ} \mathrm{C}$, a decrease in salinity of -0.3 , and a decrease in $\mathrm{pH}$ by $-0.25-0.30$ units $[8,21]$. These results are in agreement with the results obtained over other active hydrothermal vents. Temperature and salinity anomalies of $+1.0{ }^{\circ} \mathrm{C}$ and -0.21 , respectively, were obtained in the interior of a crater of the Vailulu'u seamount at a $950 \mathrm{~m}$ depth in Samoa [53], and temperature and salinity anomalies up to $+3.0^{\circ} \mathrm{C}$ and -0.15 , respectively, were found in the interior of the Kolumbo submarine volcano at a $500 \mathrm{~m}$ depth in Santorini [55]. Moreover, our pH 
values seem to be similar to those obtained over the Ahyi (-0.5), NW Rota $(-0.73)$, West Mata (-1.51), Nikko (-0.16), Daikoku (-0.05), and Kasuga-2 (-0.313) hydrothermal plumes [56-59].

Cyclic behavior has been recognized at a number of open-vent volcanoes around the world. Pulsatory patterns in both degassing [25,32,33,60] and in the behavior of active lava lakes [61,62] have been observed. High-time resolution thermal image datasets recorded at Etna, Stromboli, and Kilauea volcanoes retrieved cycles that vary within similar time windows, grouped into three main classes: (i) cycles with periods $<15 \mathrm{~s}$ related to Sharp pulses in the thermal signal (gas puff/discrete Strombolian explosions; [63]); (ii) periods between 20-50 s and 1-10 min associated with the bursting of hot, over-pressured gas bubbles/trains of bubbles [64] at the magma-air interface; and (iii) long cycles with periods of 12-90 min reflecting dynamics occurring within the shallow magma supply system [24]. For decades, Stromboli has been an ideal laboratory for studying the different modes and rates of gas release from active volcanoes. In fact, its active degassing (explosions and puffing) plays a key role in modulating a longer term cyclic (periods 300-700 s) $\mathrm{SO}_{2}$ degassing behavior, which represents a key target to be explored in future research [60]. Cyclic volcanic degassing behaviors have also been characterized in the release of gas flux for Mount Etna at two period bands (40-250 s and 500-1200 s), which suggest a bursting of rising gas bubble trains at the magma-air interface [25]. Cyclic degassing of the Erebus volcano in Antarctica has also been registered in the total gas column amount, a likely proxy for gas flux, with periods of 10 , 35 , and $70 \mathrm{~min}$, which can be explained in terms of chemical equilibria and pressure-dependent solubility [26]. Cyclic behavior with spattering episodes of 40-100 $\mathrm{m}$ in a lava pool was first documented in Kilauea volcano [62].

Subaerial and submarine eruptions are often thought of in very different terms due to the sharp contrast between quench conditions in air and water. The same surprising similarities were found at NW Rota-1 in the spine-growth velocities, which control the syn-ascent crystallization and degassing [65]. For submarine eruptions driven by magmatic degassing, temporally cyclic behavior appears to be a fundamental characteristic at a wide range of extrusion rates [65]. In submarine ambient conditions, the tidal cycle seems to be of greater importance in the driving forces of these variations $[18,23,66]$. Other periods exist that may be generated by the turbulent mixing occurring in this environment, by changes due to the directions of local currents, and/or by variations in the hydrothermal fluid discharge $[3,66,67]$. In our case, variations in the in situ pressure sensor data show that the total signal of the tide is explained by the M2 type at $97.3 \%$ of the total variance with a mean amplitude of $0.92 \pm 0.02 \mathrm{~m}$, a period of $12 \mathrm{~h}$, and negligible velocity relative to the predominant local mean current [54]. Although our data, before filtering the low frequencies, presents a tidal relationship, the behavior shown in Figures 5 and 6 presented a period too short to depend on the existing M2 type tide of the area, as was also reported in other similar studies $[18,23,66]$. Moreover, the velocity observation with a vessel-mounted acoustic doppler current profiler (VMADCP) indicates that the local current intensities in the area were very low $(1.5 \pm 1.0 \mathrm{~cm} / \mathrm{s})$ and stable, with a main southward direction [21].

Although cyclicity studies at submarine hydrothermal vents are less frequent that those at subaerial vents, hydrophone records at NW Rota-1 show that bursts of Strombolian explosive degassing at the volcano summit (520 m deep) occurred at 1-2 min intervals during the entire 12-month time series, and commonly exhibited cyclic step-function changes between high and low intensity [35]. Other studies have interrelated the cyclicity of eruptive activity with mass wasting at submarine arc volcanoes [65]. Moreover, time-series of temperature and velocities over a diffuse flow at Juan de Fuca Ridge show evidence of cyclic modulation of $12.4 \mathrm{~h}, 16-17 \mathrm{~h}$, and four to five day periods, suggesting that temperature variability correlates with the variability of the current speed and direction, not with the ocean's tidal pressure [18]. Thus, the modulation of temperature by tides is only indirect, through the modulation of horizontal bottom currents. In our case, and in order to avoid the effect of the tide, frequencies higher than $6 \mathrm{~h}$ were removed from our data. Our filtered time-series reflect cyclic behaviors of frequencies higher than the semi-diurnal tide period. 
Tagoro is the first submarine volcano in the Canary Islands region that presents a clear cyclic behavior in the release of heat and gases during its degasification phase. This cyclic behavior (130-170 $\mathrm{min}$ ) is in the same order of the longest cycles found for Etna, Stromboli, Kilauea, and Erebus volcanoes [24,26], although more information is needed to establish possible cyclic patterns in higher frequencies from seconds to minutes.

\section{Conclusions}

The variability and duration of cyclic events provide new and relevant information for tracking and constraining the associated physical-chemical processes and their effects on the marine ecosystems linked to shallow submarine degassing areas. In addition, such information can also provide a warning of future eruptions in the area, since it is hypothesized that in complex, non-linear natural systems, drastic changes or tipping points are often preceded by a period of enhanced variability $[68,69]$.

Our results highlight that the submarine volcano Tagoro is still active in its degasification phase, five years after its origin, with significant physical-chemical anomalies of up to $+2.55^{\circ} \mathrm{C}$ in temperature, -1.02 in salinity, and -1.25 units in $\mathrm{pH}$. Moreover, our results, obtained by the application of two different time-domain-frequency analysis techniques to the filtered time series of potential temperature, salinity, pressure, $\mathrm{pH}$, and ORP, show a strong peak of over $99.9 \%$ significance centered at approximately $140 \mathrm{~min}$ and immersed in a significant interval of 130-170 $\mathrm{min}$, alternated between periods of high and low activity. For all of this, Tagoro has been the first submarine volcano at the Canary archipelago presenting a clear cyclic behavior in its degassing process at frequencies higher than the semidiurnal M2 tide. Although this cyclic behavior may be related to variations in hydrothermal fluid discharge that reflect dynamics occurring within the magmatic system [24] or cyclic dynamic processes occurring in the conduit system [70], we encourage the further use of time-frequency analysis using longer and higher temporal resolution observations recorded by a permanent mooring in the area, and their comparison and integration with geophysical parameters. Variability studies of these cyclic behaviors represent a key target to be studied in order to understand the complex degassing dynamic of these hydrothermal systems.

Author Contributions: Study design: E.F.N., J.M.S.C., and M.G.D. Data processing and graphical representations: E.F.N. and O.S.G. High resolution bathymetry and deployment: E.F.N., J.TV., L.M.F.S., D.P., O.S.G., J.M.S.C., and M.G.D. Writing of the manuscript, conclusion, and discussion of the results: E.F.N., J.M.S.C., M.G.D., J.T.V., L.M.F.S., D.P., O.S.G., and C.P.N.

Funding: This research was funded by Ministerio de Economía y Competitividad del Gobierno de España (MINECO) and FEDER through VULCANO (CTM2012-36317) and VULCANO-II (CTM2014-51837-R) projects and funds from The Spanish Institute of Oceanography (IEO) through the VULCANA (IEO-2015-2017) project. The use of the ROV Liropus 2000 was also funded by IEO.

Acknowledgments: The authors would like to thank the officers and crew of the R/V Ramón Margalef and Ángeles Alvariño from the Spanish Institute of Oceanography for their help at sea. We would also like to thank the technician team of ACSM for their help at sea during the cruise and for the recovering of the mooring with the ROV. We are grateful to three anonymous reviewers and the journal editor for their comments, which greatly improved the quality of the paper.

Conflicts of Interest: The authors declare no conflict of interest.

\section{References}

1. Fricke, H.; Giere, O.; Stetter, K.; Alfredsson, G.A.; Kristjansson, J.K.; Stoffers, P.; Svavarsson, J. Hydrothermal vent communities at the shallow subpolar Mid-Atlantic ridge. Mar. Biol. 1989, 102, 425-429. [CrossRef]

2. Botz, R.; Winckler, G.; Bayer, R.; Schmitt, M.; Schmidt, M.; Garbe-Schönberg, D.; Stoffers, P.; Kristjansson, J.K. Origin of trace gases in submarine hydrothermal vents of the Kolbeinsey Ridge, north Iceland. Earth Planet. Sci. Lett. 1999, 171, 83-93. [CrossRef]

3. Dando, P.R.; Stüben, D.; Varnavas, S.P. Hydrothermalism in the Mediterranean Sea. Prog. Oceanogr. 1999, 44, 333-367. [CrossRef] 
4. Cardigos, F.; Colaço, A.; Dando, P.R.; Ávila, S.P.; Sarradin, P.M.; Tempera, F.; Conceição, P.; Pascoal, A.; Serrão Santos, R. Shallow water hydrothermal vent field fluids and communities of the D. João de Castro Seamount (Azores). Chem. Geol. 2005, 224, 153-168. [CrossRef]

5. Furushima, Y.; Nagao, M.; Suzuki, A.; Yamamoto, H.; Maruyama, T. Periodic behavior of the bubble jet (Geyser) in the taketomi submarine hot springs of the southern part of yaeyama archipelago Japan. Mar. Technol. Soc. J. 2009, 43, 13-22. [CrossRef]

6. Butterfield, D.A.; Massoth, G.J.; McDuff, R.E.; Lupton, J.E.; Lilley, M.D. Geochemistry of hydrothermal fluids from Axial Seamount hydrothermal emissions study vent field, Juan de Fuca Ridge: Subseafloor boiling and subsequent fluid-rock interaction. J. Geophys. Res. 1990, 95, 12895-12921. [CrossRef]

7. Tassi, F.; Capaccioni, B.; Caramanna, G.; Cinti, D.; Montegrossi, G.; Pizzino, L.; Quattrocchi, F.; Vaselli, O. Low-pH waters discharging from submarine vents at Panarea Island (Aeolian Islands, southern Italy) after the 2002 gas blast: Origin of hydrothermal fluids and implications for volcanic surveillance. Appl. Geochem. 2009, 24, 246-254. [CrossRef]

8. Campbell, A.C.; Edmond, J.M. Halide systematics of submarine hydrothermal vents. Nature 1989, 342, $168-170$. [CrossRef]

9. Thompson, G. Hydrothermal Fluxes in the Ocean. In Chemical Oceanography; Elsevier: London, UK, 1983; pp. 271-337.

10. Von Damm, K.L. Seafloor Hydrothermal Activity: Black Smoker Chemistry And Chimneys. Ann. Rev. Earth Planet. Sci. 1990, 18, 173-204.

11. Rona, P.A.; Bemis, K.G.; Jones, C.D.; Jackson, D.R.; Mitsuzawa, K.; Silver, D. Entrainment and bending in a major hydrothermal plume, Main Endeavour Field, Juan de Fuca Ridge. Geophys. Res. Lett. 2006, 33, L19313. [CrossRef]

12. Prol-Ledesma, R.M.; Canet, C.; Torres-Vera, M.A.; Forrest, M.J.; Armienta, M.A. Vent fluid chemistry in Bahía Concepción coastal submarine hydrothermal system, Baja California Sur, Mexico. J. Volcanol. Geotherm. Res. 2004, 137, 311-328. [CrossRef]

13. Wenzhöfer, F.; Holby, O.; Glud, R.N.; Nielsen, H.K.; Gundersen, J.K. In situ microsensor studies of a shallow water hydrothermal vent at Milos, Greece. Mar. Chem. 2000, 69, 43-54. [CrossRef]

14. Tarasov, V.G.; Gebruk, A.V.; Mironov, A.N.; Moskalev, L.I. Deep-sea and shallow-water hydrothermal vent communities: Two different phenomena? Chem. Geol. 2005, 224, 5-39. [CrossRef]

15. Aliani, S.; Bortoluzzi, G.; Caramanna, G.; Raffa, F. Seawater dynamics and environmental settings after November 2002 gas eruption off Bottaro (Panarea, Aeolian Islands, Mediterranean Sea). Cont. Shelf Res. 2010, 30, 1338-1348. [CrossRef]

16. Tudino, T.; Bortoluzzi, G.; Aliani, S. Shallow-water gaseohydrothermal plume studies after massive eruption at Panarea, Aeolian Islands, Italy. J. Mar. Syst. 2014, 131, 1-9. [CrossRef]

17. Heinicke, J.; Italiano, F.; Maugeri, R.; Merkel, B.; Pohl, T.; Schipek, M.; Braun, T. Evidence of tectonic control on active arc volcanism: The Panarea-Stromboli tectonic link inferred by submarine hydrothermal vents monitoring (Aeolian arc, Italy). Geophys. Res. Lett. 2009, 36, L04301. [CrossRef]

18. Tivey, M.K.; Bradley, A.M.; Joyce, T.M.; Kadko, D. Insights into tide-related variability at seafloor hydrothermal vents from time-series temperature measurements. Earth Planet. Sci. Lett. 2002, 202, 693-707. [CrossRef]

19. Bayona, J.M.; Monjonell, A.; Miquel, J.C.; Fowler, S.W.; Albaigés, J. Biogeochemical characterization of particulate organic matter from a coastal hydrothermal vent zone in the Aegean Sea. Org. Geochem. 2002, 33, 1609-1620. [CrossRef]

20. Tarasov, V.G.; Propp, M.V.; Propp, L.N.; Zhirmunsky, A.V.; Namsakakv, B.B.; Gorlenko, V.M.; Starynin, D.A. Shallow-Water Gasohydrothermal Vents of Ushishir Volcano and the Ecosystem of Kraternaya Bight (The Kurile Islands). Mar. Ecol. 1990, 11, 1-23. [CrossRef]

21. Santana-Casiano, J.M.; Fraile-Nuez, E.; González-Dávila, M.; Baker, E.T.; Resing, J.A.; Walker, S.L. Significant discharge of $\mathrm{CO}_{2}$ from hydrothermalism associated with the submarine volcano of El Hierro Island. Sci. Rep. 2016, 6, 1-9. [CrossRef]

22. Chance, A.; Kelly, P.M. An apparent periodicity in an index of volcanic activity. Nature 1979, 280, 671-672. [CrossRef] 
23. Aliani, S.; Meloni, R.; Dando, P.R. Periodicities in sediment temperature time-series at a marine shallow water hydrothermal vent in Milos Island (Aegean Volcanic arc, Eastern Mediterranean). J. Mar. Syst. 2004, 46, 109-119. [CrossRef]

24. Spampinato, L.; Oppenheimer, C.; Cannata, A.; Montalto, P.; Salerno, G.G.; Calvari, S. On the time-scale of thermal cycles associated with open-vent degassing. Bull. Volcanol. 2012, 74, 1281-1292. [CrossRef]

25. Tamburello, G.; Aiuppa, A.; McGonigle, A.J.S.; Allard, P.; Cannata, A.; Giudice, G.; Kantzas, E.P.; Pering, T.D. Periodic volcanic degassing behavior: The Mount Etna example. Geophys. Res. Lett. 2013, 40, 4818-4822. [CrossRef]

26. Ilanko, T.; Oppenheimer, C.; Burgisser, A.; Kyle, P. Cyclic degassing of Erebus volcano, Antarctica. Bull. Volcanol. 2015, 77, 56. [CrossRef]

27. Chouet, B.A. Long-period volcano seismicity: Its source and use in eruption forecasting. Nature 1996, 380, 309-316. [CrossRef]

28. Ripepe, M.; Marchetti, E.; Bonadonna, C.; Harris, A.J.L.; Pioli, L.; Ulivieri, G. Monochromatic infrasonic tremor driven by persistent degassing and convection at Villarrica Volcano, Chile. Geophys. Res. Lett. 2010, 37, 15. [CrossRef]

29. Blake, S. Volatile oversaturation during the evolution of silicic magma chambers as an eruption trigger. J. Geophys. Res. 1984, 89, 8237. [CrossRef]

30. Dingwell, D.B. Magma degassing and fragmentation: Recent experimental advances. In From Magma to Tephra-Modelling Physical Processes of Explosive Volcanic Eruptions; Elsevier: Amsterdam, The Netherland, 1998.

31. Varley, N.R.; Taran, Y. Degassing processes of Popocatépetl and Volcán de Colima, Mexico. Geol. Soc. Lond. Spec. Publ. 2003, 213, 263-280. [CrossRef]

32. Edmonds, M.; Herd, R.A.; Galle, B.; Oppenheimer, C.M. Automated, high time-resolution measurements of SO2 flux at Soufrière Hills Volcano, Montserrat. Bull. Volcanol 2003, 65, 578-586. [CrossRef]

33. Pering, T.D.; Tamburello, G.; McGonigle, A.J.S.; Aiuppa, A.; Cannata, A.; Giudice, G.; Patanè, D. High time resolution fluctuations in volcanic carbon dioxide degassing from Mount Etna. J. Volcanol. Geotherm. Res. 2014, 270, 115-121. [CrossRef]

34. Peters, N.; Oppenheimer, C.; Killingsworth, D.R.; Frechette, J.; Kyle, P. Correlation of cycles in Lava Lake motion and degassing at Erebus Volcano, Antarctica. Geochem. Geophys. Geosyst. 2014, 15, 3244-3257. [CrossRef]

35. Dziak, R.P.; Baker, E.T.; Shaw, A.M. Flux measurements of explosive degassing using a yearlong hydroacoustic record at an erupting submarine volcano. Geochemistry 2012. [CrossRef]

36. O'Hara, S.; Dando, P.R.; Schuster, U.; Bennis, A. Gas seep induced interstitial water circulation: Observations and environmental implications. Cont. Shelf Res. 1995, 15, 931-948. [CrossRef]

37. Botz, R.; Stüben, D.; Winckler, G.; Bayer, R.; Schmitt, M.; Faber, E. Hydrothermal gases offshore Milos Island, Greece. Chem. Geol. 1996, 130, 161-173. [CrossRef]

38. Riedel, C.; Schmidt, M.; Botz, R.; Theilen, F. The Grimsey hydrothermal field offshore North Iceland: Crustal structure, faulting and related gas venting. Earth Planet. Sci. Lett. 2001, 193, 409-421. [CrossRef]

39. Botz, R.; Wehner, H.; Worthington, T.J.; Schmidt, M.; Stoffers, P. Thermogenic hydrocarbons from the offshore Calypso hydrothermal field, Bay of Plenty, New Zealand. Chem. Geol. 2002, 186, 235-248. [CrossRef]

40. De Ronde, C.E.J.; Stoffers, P.; Garbe-Schönberg, D.; Christenson, B.W.; Jones, B.; Manconi, R.; Browne, P.R.L.; Hissmann, K.; Botz, R.; Davy, B.W.; et al. Discovery of active hydrothermal venting in Lake Taupo, New Zealand. J. Volcanol. Geotherm. Res. 2002, 115, 257-275. [CrossRef]

41. Forrest, M.J.; Ledesma-Vázquez, J.; Ussler, W., III; Kulongoski, J.T.; Hilton, D.R.; Greene, H.G. Gas geochemistry of a shallow submarine hydrothermal vent associated with the El Requesón fault zone, Bahía Concepción, Baja California Sur, México. Chem. Geol. 2005, 224, 82-95. [CrossRef]

42. McCarthy, K.T.; Pichler, T.; Price, R.E. Geochemistry of Champagne Hot Springs shallow hydrothermal vent field and associated sediments, Dominica, Lesser Antilles. Chem. Geol. 2005, 224, 55-68. [CrossRef]

43. Hall-Spencer, J.M.; Rodolfo-Metalpa, R.; Martin, S.; Ransome, E.; Fine, M.; Turner, S.M.; Rowley, S.J.; Tedesco, D.; Buia, M.-C. Volcanic carbon dioxide vents show ecosystem effects of ocean acidification. Nature 2008, 454, 96-99. [CrossRef]

44. Fraile-Nuez, E.; González-Dávila, M.; Santana-Casiano, J.M.; Arístegui, J.; Alonso-González, I.J.; Hernández-León, S.; Blanco, M.J.; Rodríguez-Santana, A.; Hernández-Guerra, A.; Gelado-Caballero, M.D.; 
et al. Erratum: The submarine volcano eruption at the island of El Hierro: Physical-chemical perturbation and biological response. Sci. Rep. 2012, 2, 1-6. [CrossRef]

45. Santana-Casiano, J.M.; González-Dávila, M.; Fraile-Nuez, E.; De Armas, D.; González, A.G.; Domínguez-Yanes, J.F.; Escanez, J. The natural ocean acidification and fertilization event caused by the submarine eruption of El Hierro. Sci. Rep. 2013, 3, 1-8. [CrossRef] [PubMed]

46. Lomb, N.R. Least-squares frequency analysis of unequally spaced data. Astrophys. Space Sci. 1976, 39, 447-462. [CrossRef]

47. Scargle, J.D. Studies in astronomical time series analysis. II-Statistical aspects of spectral analysis of unevenly spaced data. The Astrophys. J. 1982, 263, 835-853. [CrossRef]

48. Daubechies, I. The wavelet transform, time-frequency localization and signal analysis. IEEE Trans. Inf. Theory 1990, 36, 961-1005. [CrossRef]

49. Fraile-Nuez, E.; Machín, F.; Vélez-Belchí, P.; López-Laatzen, F.; Borges, R.; Benítez-Barrios, V.M.; Hernández-Guerra, A. Nine years of mass transport data in the eastern boundary of the North Atlantic Subtropical Gyre. J. Geophys. Res. 2010, 115, C09009. [CrossRef]

50. Torrence, C.; Webster, P.J. Interdecadal changes in the ENSO-monsoon system. J. Climate 1999, 12, $2679-2690$. [CrossRef]

51. Grinsted, A.; Moore, J.C.; Jevrejeva, S. Application of the cross wavelet transform and wavelet coherence to geophysical time series. Nonlin. Process. Geophys. 2004, 11, 1-6. [CrossRef]

52. Massoth, G.J.; Butterfield, D.A.; Lupton, J.E.; McDuff, R.E.; Lilley, M.D.; Jonasson, I.R. Submarine venting of phase-separated hydrothermal fluids at Axial Volcano, Juan de Fuca Ridge. Nature 1989, 340, 702-705. [CrossRef]

53. Staudigel, H.; Hart, S.R.; Pile, A.; Bailey, B.E.; Baker, E.T.; Brooke, S.; Connelly, D.P.; Haucke, L.; German, C.R.; Hudson, I.; et al. Vailulu'u seamount, Samoa: Life and death on an active submarine volcano. Proc. Natl. Acad. Sci. USA 2006, 103, 6448-6453. [CrossRef]

54. Egbert, G.D.; Bennett, A.F.; Foreman, M.G.G. TOPEX/POSEIDON tides estimated using a global inverse model. J. Geophys. Res. 1994, 99, 24821-24852. [CrossRef]

55. Christopoulou, M.E.; Mertzimekis, T.J.; Nomikou, P.; Papanikolaou, D.; Carey, S.; Mandalakis, M. Influence of hydrothermal venting on water column properties in the crater of the Kolumbo submarine volcano, Santorini volcanic field (Greece). Geo-Mar.Lett. 2016, 36, 15-24. [CrossRef]

56. Resing, J.A.; Baker, E.T.; Lupton, J.E.; Walker, S.L.; Butterfield, D.A.; Massoth, G.J.; Nakamura, K.-I. Chemistry of hydrothermal plumes above submarine volcanoes of the mariana arc. Geochem. Geophys. Geosyst. 2009, 10. [CrossRef]

57. Baumberger, T.; Lilley, M.D.; Resing, J.A.; Lupton, J.E.; Baker, E.T.; Butterfield, D.A.; Olson, E.J.; Früh-Green, G.L. Understanding a submarine eruption through time series hydrothermal plume sampling of dissolved and particulate constituents: West Mata, 2008-2012. Geochem. Geophys. Geosyst. 2014, 15, 4631-4650. [CrossRef]

58. Resing, J.A.; Rubin, K.H.; Embley, R.W.; Lupton, J.E.; Baker, E.T.; Dziak, R.P.; Baumberger, T.; Lilley, M.D.; Huber, J.A.; Shank, T.M.; et al. Active submarine eruption of boninite in the northeastern Lau Basin. Nat. Geosci. 2011, 4, 799-806. [CrossRef]

59. Buck, N.J.; Resing, J.A.; Baker, E.T.; Lupton, J.E. Chemical Fluxes From a Recently Erupted Shallow Submarine Volcano on the Mariana Arc. Geochem. Geophys. Geosyst. 2018, 19, 1660-1673. [CrossRef]

60. Tamburello, G.; Aiuppa, A.; Kantzas, E.P.; McGonigle, A.J.S.; Ripepe, M. Passive vs. active degassing modes at an open-vent volcano (Stromboli, Italy). Earth Planet. Sci. Lett. 2012, 359-360, 106-116. [CrossRef]

61. Bouche, E.; Vergniolle, S.; Staudacher, T.; Nercessian, A.; Delmont, J.C.; Frogneux, M.; Cartault, F.; Le Pichon, A. The role of large bubbles detected from acoustic measurements on the dynamics of Erta 'Ale lava lake (Ethiopia). Earth Planet. Sci. Lett. 2010, 295, 37-48. [CrossRef]

62. Patrick, M.R.; Orr, T.; Wilson, D.; Dow, D.; Freeman, R. Cyclic spattering, seismic tremor, and surface fluctuation within a perched lava channel, Kīlauea Volcano. Bull. Volcanol. 2011, 73, 639-653. [CrossRef]

63. Harris, A.; Johnson, J.; Horton, K.; Garbeil, H.; Ramm, H.; Pilger, E.; Flynn, L.; Mouginis-Mark, P.; Pirie, D.; Donegan, S.; et al. Ground-based infrared monitoring provides new tool for remote tracking of volcanic activity. Eos Trans. Am. Geophys. Union 2003, 84, 409-418. [CrossRef]

64. Blackburn, E.A.; Wilson, L.; Sparks, R.S.J. Mechanisms and dynamics of strombolian activity. J. Geol. Soc. 1976, 132, 429-440. [CrossRef] 
65. Schnur, S.R.; Chadwick, W.W.; Embley, R.W.; Ferrini, V.L.; De Ronde, C.E.J.; Cashman, K.V.; Deardorff, N.D.; Merle, S.G.; Dziak, R.P.; Haxel, J.H.; et al. A decade of volcanic construction and destruction at the summit of NW Rota-1 seamount: 2004-2014. J. Geophys. Res. Solid Earth 2017, 122, 1558-1584. [CrossRef]

66. Chevaldonné, P.; Desbruyères, D.; Haître, M.L. Time-series of temperature from three deep-sea hydrothermal vent sites. Deep Sea Res. Part. A. Oceanogr. Res. Papers 1991, 38, 1417-1430. [CrossRef]

67. Schultz, A.; Dickson, P.; Elderfield, H. Temporal variations in diffuse hydrothermal flow at TAG. Geophys. Res. Lett. 1996, 23, 3471-3474. [CrossRef]

68. Lenton, T.M. Early warning of climate tipping points. Nature Clim. Change 2011, 1, 201-209. [CrossRef]

69. Wilson, C.J.N. Volcanoes: Characteristics, tipping points, and those pesky unknown unknowns. Elements 2017, 13, 41-46. [CrossRef]

70. Ripepe, M.; Harris, A.J.L.; Marchetti, E. Coupled thermal oscillations in explosive activity at different craters of Stromboli volcano. Geophys. Res. Lett. 2005, 32, 1-4. [CrossRef]

(C) 2018 by the authors. Licensee MDPI, Basel, Switzerland. This article is an open access article distributed under the terms and conditions of the Creative Commons Attribution (CC BY) license (http://creativecommons.org/licenses/by/4.0/). 